\title{
Evaluation of Some Immunostimulants on the Immune-response of Broiler Chickens Against Avian Influenza and Newcastle Diseases Vaccination Mohamed S. Abdel-Hafez ${ }^{1}$, Moemen A. Mohamed ${ }^{2 *}$
}

\author{
${ }^{1}$ Poultry Diseases Department, Faculty of Veterinary Medicine, New Valley, Assiut University, \\ NewValley, Egypt \\ ${ }^{2}$ Poultry Diseases Department, Faculty of Veterinary Medicine, Assiut University, Assiut, Egypt
}

\begin{abstract}
Immunostimulants get an increasing importance to enhance the immune system and allowing maximum performance in poultry production. The effects of using different immunostimulants on the immune response of broiler chickens to Newcastle disease (ND) and Avian influenza (AI) vaccination were investigated in this study. 100 day-old Ross broiler chicks were randomly divided into 4 groups, 25 birds for each group. Group A was not treated with any immunostimulants and used as a control, while groups B, C and D were supplemented with Imutrix $^{\circledR}$ (oregano oils plus $\beta$-glucan), Evit liquid ${ }^{\circledR}$ (Vitamin E plus selenium) and inmunair ${ }^{\circledR} 17.5$ (Propionibacterium acnes and E. coli lipopolysaccharides), respectively. Statistical analysis results demonstrated significant divergence $(P<0.05)$ in body weight $(\mathrm{BW})$ and feed conversion ratio among the applicable treatments. Birds of group B had the heaviest body weight $(2.03 \mathrm{~kg})$, followed by group $\mathrm{C}(1.87 \mathrm{Kg})$ and $\mathrm{D}(1.82 \mathrm{Kg})$ in comparison to the birds of group A (control, $1.79 \mathrm{Kg}$ ). Bursa of Fabricius weight showed non-significant differences among groups except in group B that showed an increase in the Bursa of Fabricius weight more than other groups especially the control group (1.15 g more). Comparable immune response was recorded for both AI and ND vaccination. The highest mean antibody titers were recorded for birds in group B at 14, 28 and 35 days old, while those in group D had the lowest antibody titre values. Thus, supplementing immunostimulants especially Imutrix ${ }^{\circledR}$ and Evit liquid ${ }^{\circledR}$ had a significant positive effect on performance characteristics and immune response against AI and ND vaccination in broiler chickens in contrast to non-treated group, which had low levels of immune response, rapid decreasing and no persistence for keeping high HI titer for long time.
\end{abstract}

Keywords: Immunostimulants, Immune response, Broiler chickens, Avian influenza, Newcastle, Vaccination.

\section{Introduction}

Infectious diseases are the chief challenge in the commercial poultry industry. Newcastle disease (ND) and avian influenza (AI) are considered the most somber worldwide diseases affecting poultry flocks which causing stark economic losses to the poultry industry [1]. Both of them can be controlled by bird vaccination using both live and inactivated virus vaccines [2,3]. Despite the use of the available vaccines, disease outbreaks are still common due to variety of stresses of intensive production systems, high density, nutritional and antibiotic administration as well as immunosuppression that adversely affect the immune status of the birds [4,5]. Thus, there is a need to improve the immune response of ND and AI vaccines

to produce respectable antibody titers that can reduce viral replication. This enhancement can be achieved by using of adjuvants and/or immunostimulant supplements. Therefore, immunostimulants have been used as adjuvants to give long lasting humoral and cellular immune responses and improving the response of vaccines $[6,7]$.

Immunostimulants consist of a cluster of biological and synthetic compounds that boost the non-specific cellular immunity by activating macrophages which consequently stimulate the immune response such as antigen engulf, cell killing, cytokine release and creation of antibody as well as humoral defense mechanisms in animals [8] which increases the sustainability of immune

*Corresponding author e-mail: (moemenmohamed@aun.edu.eg), Poultry Diseases Department, Faculty of Veterinary Medicine, Assiut University, Assiut, Egypt. 
response to the infectious agent and resistance to disease infections [9,10]. Antioxidants, vitamin $\mathrm{E}$ and selenium (Se), play an important role in caring cells from reactive oxygen (RO) by free radical reduction and stopping the lipid peroxidation [11]. Vitamin E is the main lipid soluble antioxidant present in the cell membrane [12] and provides the first defense line against oxidative damage. Selenium (Se) is an essential component of the enzymes, Se-dependent glutathione peroxidases, which reduce hydrogen peroxide and lipid hydroperoxides [13]. Selenium addition to chickens infested with coccidia created changes in the numbers of blood leucocytes, revealing that Se possibly improves resistance to infection [14]. Therefore, it is not astonishing that deficiency of $\mathrm{Se}$ or vitamin $\mathrm{E}$ seriously affects immunological functions $[15,16]$. A combination of selenium and vitamin E play a major role in the development and maintenance of defense systems.

Inmunair $17.5^{\circledR}$ (Propionibacterium acnes, and $E$. coli lipopolysaccharides) is one of the commercial products available in the Egyptian market as nonspecific immunostimulant for the chicken farms. Propionibacterium acnes is a Gram positive, non-spore forming opportunistic bacteria [17]. P. acnes is an effective activator of macrophage, lymphocyte, natural killer cells and cytokine release in the examined lab animals [18]. Lipopolysaccharides are the main components of the outer membrane of Gram-negative bacteria, induce strong immune responses. Lipopolysaccharides of Escherichia coli (LPS) had a role in releasing IL-1, IL-6, or tumor necrosis factor (TNF) by macrophages [19].

Oregano essential oils (OEO) are extracted from Origanumvulgare plants (leaves and flowers). They consist of more than 30 ingredients, most of which are carvacrol and thymol that constitute $78-82 \%$ of oregano essential oil [20]. Oregano essential oils have potent antioxidant effects, which inhibit the oxidative reactions that exert on phospholipid membranes [21]. They support increasing the proportion of differentiation (CD) molecules of lymphocytes $\mathrm{CD} 4+$ and $\mathrm{CD} 8+$ ( $\mathrm{T}$ lymphocyte), in pigs fed oregano in contrast to control ones [22]. $\beta$-Glucans are glucose molecules that considered the base components of cell wall of several bacteria, fungi, algae and yeast [23]. $\beta$-glucans activated the immune cells, macrophages, dendritic cells neutrophils, B cells, T cells, and natural killer cells [24]. The intensification of specific immunity (humoral and cell-mediated) will increase the animal's ability to resist diseases. Therefore, the present study was undertaken to investigate the immunomodulatory effects of the different immunostimulants on antibody response and performance against routine vaccination of $\mathrm{ND}$ and $\mathrm{AI}$ in broiler chickens.

\section{Material and Methods}

\section{Chickens and experimental design}

A total of 100 one-day-old broiler chicks (male and female Ross), were weighed and randomly divided into four groups on arrival. All groups received AI and ND vaccines; group $\mathrm{A}$ is control (vaccinated non treated birds); group $\mathrm{B}$ was treated with (imutrix ${ }^{\circledR}$ ) in a dose of $1.5 \mathrm{ml} / \mathrm{L}$ to drinking water for 24 hours at the first three days of every week along the period of experiment. Group $\mathrm{C}$ was treated by Vit $\mathrm{E}$ and selenium with the same regimen of administration and group D was similarly supplemented with inmunair 17.5. Chicks were raised on floor for 5 weeks and had free access to feed (Elwadi feed Co., Egypt) and water throughout the entire experimental period. The lighting program was $23 \mathrm{~h}$ light and $1 \mathrm{~h}$ of darkness. The temperature was gradually decreased from 33 to $25^{\circ} \mathrm{C}$ on day 21 and then was kept constant.

\section{Vaccination schedule}

The birds of all groups were vaccinated against ND via eye drop at $7^{\text {th }}$ day of age (HB1, Pfizer), $15^{\text {th }}$ day of age (LaSota, Pfizer) and at 21 days of age (clone30, Izovac). AI (Nobilis, H5N2) vaccination was given one $\mathrm{S} / \mathrm{C}$ shot at the $5^{\text {th }}$ day of age using killed (H5N2). Gumboro (Pfizer) disease vaccination was applied at $11^{\text {th }}$ day of age with intermediate strain vaccine via eye drop route.

\section{Immunostimulants}

Purified $\beta$ - glucan $11 \mathrm{~g}$ and oregano oils essential oils $120 \mathrm{~g}$ (carvacrol $60 \mathrm{~g}+$ thymol $3.6 \mathrm{~g}$ ) in demineralized water up to 1 liter emulsifiers produced commercially under the trade name "Imutrix ${ }^{\circledR} "$ (ELT Co., South 
Korea) were used. Vitamin E and selenium produced commercially under the trade name "EVIT LIQUID®" (Tecnozoo Co., ITALIA) were used. The Inmunair $17.5^{\circledR}$ (LABORATORIOS CALIER SA) which consists of (inactivated cells of propionibacterium acnes $0.17 \mathrm{mg}$, lipopolysaccharide from E. coli $0.05 \mathrm{mg}$, Thiomersal, $0.10 \mathrm{mg}$ and Excipient q.s $1 \mathrm{ml}$ ).

\section{Immunological measurements}

Sera for determing the HI titre

Blood samples were collected from the wing and brachial veins of 5 birds randomly selected from each treatment at the $7,14,21$, 28,35 days into tubes without anticoagulant to determine the antibody titre following vaccination against ND and AI. Blood samples were dated and labeled according to number of chickens and groups. Samples were centrifuged for $10 \mathrm{~min}$ at $3000 \mathrm{rpm}$ to obtain serum then were divided into aliquots and stored in Eppendorf tubes at $-20^{\circ} \mathrm{C}$ until analysis.

\section{HI test}

Two fold serial dilutions of the collected sera $(50 \mu \mathrm{L})$ were prepared, then 4 HA units of NDV and AIV were prepared and added to each dilution. Subsequently, 30 minutes of incubation, $50 \mu \mathrm{L}$ of $0.5 \%$ washed chicken red blood cells (RBC) was added on each well, the blend was incubated for $30 \mathrm{~min}$ at room temperature. Hemagglutination inhibition endpoint (the highest dilution of serum cause complete inhibition) were scored and recorded as reciprocal $\log _{2}$ values of the highest dilution of HI.

\section{Bursa index}

Birds were weighed and then slaughtered. The bursa of Fabricius was directly removed and weighed from 5 birds per group. The immune organ index was calculated: organosomatic index =organ weight $(\mathrm{g}) /$ body weight (kg) [25].

\section{Performance}

The experimental period duration was 35 days. On day 7, 14, 21, 28 and 35 birds were weighed by group. For weight measurement, individual birds were weighed and the mean weight of each group was calculated. Feed conversion ratio (FCR) was estimated as the amount of feed it takes to grow a kilogram. (https://en.wikipedia.org/wiki/Feed_conversio n_ratio\#Poultry).

\section{Statistical analysis}

Data were analyzed by one-way ANOVA using SPSS14 and Duncan's multiple range test was used to compare the means $(\mathrm{P}<0.05)$.

\section{Results}

Impacts of different immunostimulants on weight gain of broilers at different ages were presented in Table (1). The average of total BW of treated groups was higher than that observed in the control group along the experimental period but the difference was non-significant except group $\mathrm{B}$; the body weights tended to significantly increase $(P>$ 0.05 ) at days 28 and 35 in comparison to group A (table 1). As presented in Table (2), the FCR of control group (1.503) was higher than treated groups $(1.33,1.406$ and 1.42 for group $\mathrm{B}, \mathrm{C}$ and $\mathrm{D}$, respectively), which was significantly lower in group B at day 35 in comparison to control group. According to the results shown in Table (3), There was an increase in the bursa weight of birds that were treated with imutrix (group B) at day 35 of age $(2.78 \mathrm{~g})$ which was $1.15 \mathrm{~g}$ increased from the weight of control group.

Table 1: Average body weights of broiler chickens (g) during the experimental period

\begin{tabular}{llllll}
\hline & 7 days & 14 days & 21 days & 28 days & 35 days \\
\hline Group A $^{1}$ & $160 \pm 0.12$ & $420 \pm 0.17$ & $825 \pm 0.43$ & $1278 \pm 0.32^{\mathrm{a}}$ & $1795 \pm 0.37^{\mathrm{a}}$ \\
Group B $^{\mathbf{2}}$ & $179 \pm 0.37$ & $454 \pm 0.42$ & $855 \pm 0.22$ & $1426 \pm 0.38^{\mathrm{b}}$ & $2030 \pm 0.15^{\mathrm{b}}$ \\
Group C $^{\mathbf{3}}$ & $180 \pm 0.25$ & $445 \pm 0.19$ & $850 \pm 0.12$ & $1340 \pm 0.26^{\mathrm{a}}$ & $1877 \pm 0.63^{\mathrm{a}}$ \\
Group D $^{\mathbf{4}}$ & $172 \pm 0.14$ & $462 \pm 0.23$ & $825 \pm 0.54$ & $1300 \pm 0.13^{\mathrm{a}}$ & $1825 \pm 0.46^{\mathrm{a}}$
\end{tabular}

1: group A was not treated with any immunostimulants and used as a control. 2: groups B was supplemented with Imutrix ${ }^{\circledR}$ (oregano oils plus $\beta$ glucan). 3: group C was supplemented with Evit liquid® (Vitamin E plus selenium). 4: group D was supplemented with inmunair ${ }^{\circledR} 17.5$ (Propionibacterium acnes and E. coli lipopolysaccharides). The means within the same column with common letter, do not have a significant difference $(\mathrm{P}>0.05)$. 
Effects of different immunostimulants treatments on humoral immune response against ND and AI vaccination were presented in Table (4). The evaluated antibody response at all intervals of the experiment starting from the day 14 revealed the AI and ND titer in control group had low levels of immune response and rapid decrease which reflected as no persistence for keeping high $\mathrm{HI}$ titer for long time (Figure 1A and 1B). Improved immunological response of AI was observed in group B at day 21, 28 and 35 by HI. At day 14, group $\mathrm{C}$ was found in the second category in the response to immunostimulant, while for response to ND vaccination, as shown in Table (4) and Figure (1B). There was a significant improvement $(P<0.05)$ of antibody titer against ND, especially in group B at day 21 , 28 and 35 followed by group $\mathrm{C}$ which significantly increased especially at day 35 of age in birds. Group D had the lowest positive effect by increase the antibody response to ND but not statistically significant $(P>0.05)$ in comparison to control group.

Table 2: Average Feed conversion ratio (FCR) of broiler chickens during the experimental period

\begin{tabular}{lllllll}
\hline & 7 days & 14 days & 21 days & 28 days & 35 days & Average \\
\hline Group A $^{\mathbf{1}}$ & $1.13 \pm 0.33$ & $1.49 \pm 0.32$ & $1.50 \pm 0.19$ & $1.60 \pm 0.14$ & $1.80 \pm 0.12^{\mathrm{a}}$ & $1.503 \pm 0.32^{\mathrm{a}}$ \\
Group B $^{2}$ & $1.00 \pm 0.02$ & $1.27 \pm 0.19$ & $1.33 \pm 0.25$ & $1.45 \pm 0.22$ & $1.60 \pm 0.53^{\mathrm{b}}$ & $1.33 \pm 0.34^{\mathrm{b}}$ \\
Group C $^{\mathbf{3}}$ & $1.00 \pm 0.10$ & $1.35 \pm 0.27$ & $1.40 \pm 0.37$ & $1.55 \pm 0.36$ & $1.73 \pm 0.14^{\mathrm{a}}$ & $1.406 \pm 0.56^{\mathrm{a}}$ \\
Group D $^{\mathbf{4}}$ & $1.00 \pm 0.02$ & $1.30 \pm 0.45$ & $1.44 \pm 0.51$ & $1.60 \pm 0.21$ & $1.76 \pm 0.27^{\mathrm{a}}$ & $1.42 \pm 0.11^{\mathrm{a}}$ \\
\hline
\end{tabular}

1: group A was not treated with any immunostimulants and used as a control. 2: groups B was supplemented with Imutrix ${ }^{\circledR}$ (oregano oils plus $\beta$ glucan). 3: group C was supplemented with Evit liquid® (Vitamin E plus selenium). 4: group D was supplemented with inmunair ${ }^{\circledR} 17.5$ (Propionibacterium acnes and E. coli lipopolysaccharides). The means within the same column with common letter, do not have a significant difference $(\mathrm{P}>0.05)$.

\section{Discussion}

It is a significant to get a good immune response to prevent viral diseases in poultry. So, the use of immune stimulants is a resolution to enhance bird's resistance to infectious diseases. Our results revealed that, the average of total BW and FCR of treated groups were higher and lower, respectively in comparison with that observed in control non treated birds along the experimental period. Group B which was supplemented with imutrix ${ }^{\circledR}$ as a source of $\beta$-glucan and oregano oil, is the only group that differed statistically in BW gain $(P<0.05)$ at day 28 and 35 in comparison to the control group. These results are in agreement with a broad idea of Iren [26] who found the submission of immune stimulating substances lead to increase the immune response that could result in enhanced growth rate and performance may be due to the decrease in the load of infectious causes and give chance to maximum performance. Also, increased the body weight of broiler chickens treated with immunostimualnts may be due to an increase in the digestive enzymes as trypsin and amylase [27-29].

Table 3: Mean bursal weight (g) and relative weight to body weight of the experimental groups at day 35

\begin{tabular}{lllll}
\hline & $\mathbf{A}^{\mathbf{1}}$ & $\mathbf{B}^{\mathbf{2}}$ & $\mathbf{C}^{\mathbf{3}}$ & $\mathbf{D}^{\mathbf{4}}$ \\
\hline Body weight $(\mathbf{k g})$ & $1.79 \pm 0.37^{\mathrm{a}}$ & $2.03 \pm 0.15^{\mathrm{b}}$ & $1.87 \pm 0.63^{\mathrm{a}}$ & $1.82 \pm 0.46^{\mathrm{a}}$ \\
Bursa weight $(\mathbf{g m})^{\text {At 35 days* }}$ & $1.63 \pm 0.12^{\mathrm{a}}$ & $2.78 \pm 0.23^{\mathrm{b}}$ & $1.47 \pm 0.34^{\mathrm{a}}$ & $1.58 \pm 0.39^{\mathrm{a}}$ \\
\hline
\end{tabular}

1: group A was not treated with any immunostimulants and used as a control. 2: groups B was supplemented with Imutrix ${ }^{\circledR}$ (oregano oils plus $\beta$ glucan). 3: group C was supplemented with Evit liquid® (Vitamin E plus selenium). 4: group D was supplemented with inmunair ${ }^{\circledR} 17.5$ (Propionibacterium acnes and E. coli lipopolysaccharides). The means within the same row with common letter, do not have a significant difference $(\mathrm{P}>0.05) .{ }^{*}$ Relative weight of bursa to body weight of the experimental groups at day 35. 
In particular, with Imutrix ${ }^{\circledR}$ treated group (a combination between $\beta$-glucan and oregano oil), our results were in concordance with Mocar et al. [30] who observed that oregano essential oils help in improving the $\mathrm{BW}$ gain of broilers through improvements of feed consumption and encouragement of proteins deposition in muscle. There was a positive effect of oregano oils on body weight gain through an increase in the feed conversion efficiency [29,31,32].

In group $\mathrm{D}$ which supplemented with Inmuonair17.5 ${ }^{\circledR} \quad$ (Propionibacterium acnes +lipopolysaccharides of $E$. coli), the increase in BW was low that was in agreement with Gaines et al., [33] and Yang et al., [34] who found that the LPS administration is a potent inflammatory inducer which elicit the proinflammatory cytokines that have an effect on BW gain as a consequence of inflammatory response. Also, Korver and Klasing [35] noted the decrease in growth rate that resulted from LPS due to the rationing of nutrient supply from growth and directed toward inflammatory immune response.

In this study, the bursal weights (as a percentage to the $\mathrm{BW}$ ) were not significantly different for experimental supplemented immunostimulants when measured at $5^{\text {th }}$ weeks of age except in group B in which there was an increase in the weight of bursa in comparison to the control group. Broilers supplemented with feed containing thyme had no considerable diversity in the spleen and bursa relative weights in comparison to control groups which was disagreed with our results [36]. In this study, the highest AI and ND HIantibody responses were emerged in birds of group B followed by group C and the least response was of group $\mathrm{D}$ in comparison to control group.

Table 4: Average $\mathrm{HI} \log _{2}$ titers of immune response against Avian Influenza and Newcastle Diseases vaccination

\begin{tabular}{|c|c|c|c|c|c|c|c|c|c|c|}
\hline \multirow[t]{2}{*}{ Groups } & \multicolumn{5}{|c|}{ AI } & \multicolumn{5}{|c|}{ ND } \\
\hline & day 7 & day 14 & day 21 & day 28 & day 35 & day 7 & day 14 & day 21 & day 28 & day 35 \\
\hline$A^{1}$ & & & $4.3 \pm 0.66^{\mathrm{a}}$ & $3.5 \pm 0.45^{\mathrm{a}}$ & $2.0 \pm 0.19^{\mathrm{a}}$ & & & $2.6 \pm 0.44^{\mathrm{a}}$ & & \\
\hline $\mathbf{B}^{2}$ & $4.8 \pm 0.34$ & $4.3 \pm 0.36$ & $5.4 \pm 0.56^{b}$ & $4.6 \pm 0.61^{b}$ & $3.5 \pm 0.34^{\mathrm{b}}$ & $6.7 \pm 0.19$ & & $6.3 \pm 0.10^{b}$ & $6.7 \pm 0.57^{b}$ & $6.2 \pm 0.21^{\mathrm{b}}$ \\
\hline $\mathbf{C}^{3}$ & $5.2 \pm 0.47$ & $4.4 . \pm 0.53$ & $5.1 \pm 0.76^{\mathrm{a}}$ & $4.2 \pm 0.51^{\mathrm{a}}$ & $3.2 \pm 0.54^{\mathrm{b}}$ & $6.3 \pm 0.61$ & $5.0 \pm 0.61$ & $5.6 \pm 0.27^{\mathrm{b}}$ & $6.2 \pm 0.74^{b}$ & $5.1 \pm 0.37^{\mathrm{a}}$ \\
\hline$D^{4}$ & $4.8 \pm 0.65$ & $4.5 \pm 0.12$ & $4.9 \pm 0.32^{\mathrm{a}}$ & $3.9 \pm 0.11^{\mathrm{a}}$ & $3.0 \pm 0.56^{\mathrm{a}}$ & $6.0 \pm 0.43$ & $4.6 \pm 0.38$ & $5.1 \pm 0.54^{b}$ & $6.0 \pm 0.66^{b}$ & $4.75 \pm 0.22^{\mathrm{a}}$ \\
\hline
\end{tabular}

1: group A was not treated with any immunostimulants and used as a control. 2: groups B was supplemented with Imutrix ${ }^{\circledR}$ (oregano oils plus $\beta$ glucan). 3: group $\mathrm{C}$ was supplemented with Evit liquid® (Vitamin E plus selenium). 4: group D was supplemented with inmunair®17.5 (Propionibacterium acnes and E. coli lipopolysaccharides). The means within the same column with common letter, do not have a significant difference $(\mathrm{P}>0.05)$.

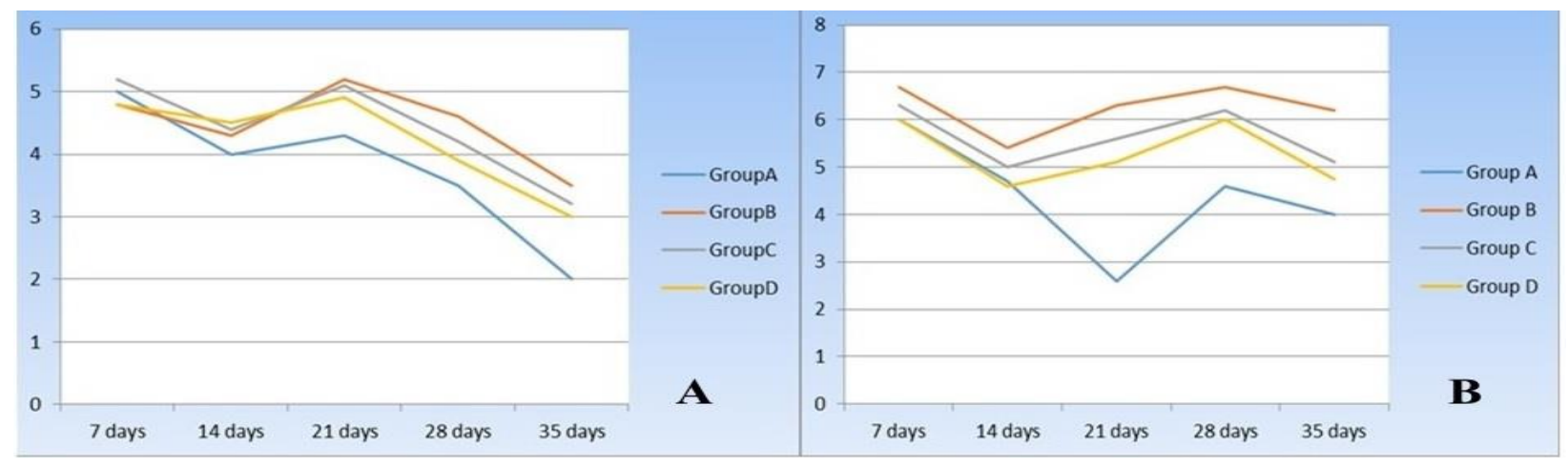

Figure 1: The immune profile of AI vaccination with immunostimulant supplementation in broiler chickens. A: The HI $\log _{2}$ titers after AI vaccination. B: The HI $\log _{2}$ titers after ND vaccination. The birds in group A were not treated, while, groups B, C and D were supplemented with Imutrix ${ }^{\circledR}$ (oregano oils plus $\beta$-glucan), Evit liquid $^{\circledR}$ (Vitamin $\mathrm{E}$ plus selenium) and inmunair ${ }^{\circledR} 17.5$ (Propionibacterium acnes and $E$. coli lipopolysaccharides), respectively. 
Similar to our results immune stimulants have antioxidant property such as thyme and Vit. E plus selenium could improve immune responses [37-39]. Acamovic and Brooker [37] investigated the mechanism of how thyme could raise the immune response and stated the immune-stimulating activity of thymol and oregano essential oil hence to the phagocyte system, cellular and humoral immunity. Also, continuous dietary application of thymol + carvacrol has a potential humoral immunostimulant activity in broilers $[29,40]$. Moreover, another study was carried to see the effect of thymol and carvarcol combination on NDV-HI specific antibody of broiler chickens and they found that those oils induced NDVHI specific antibody titers in superior manner than that mentioned with levamisole [41].

In accordance with our results of group C, the humoral immune response was improved in broilers supplemented with $132 \mathrm{mg} / \mathrm{kg}$ of vitamin $E$ than the control group $[42,43]$. Explaining the mechanism of Vitamin $\mathrm{E}$ in intensification of the immune response in birds, Moriguchi et al. [44] and Tampieri et al. [45] noticed an enhancement in macrophage phagocytic function, declining in prostaglandin $\mathrm{E}_{2}$ production, increasing IL-1 secretion by macrophages, and enhancing IL-2 production and $\mathrm{T}$-cell in broilers fed diets with high levels of Vitamin E. In particular to group $\mathrm{D}$, there was a little effect on the immune response in comparison to other treated groups, this may be in accordance with the previous researchers who found a poor humoral immune response in goats treated with $P$. acnes and attributed this to the method of administration (oral route) [46]. Also, Flaminio et al. [47] did not detect any improvement on IgG and IgM levels on foals treated with $P$. acnes.

\section{Conclusion}

In conclusion, there was a noteworthy effect of oregano essential oils with $\beta$-glucan (Imutrix ${ }^{\circledR}$ ) on BW gain at the end of the experiment. However, birds supplemented the vitamin $\mathrm{E}$ plus selenium $\left(\right.$ Evit $\left.^{\mathbb{B}}\right)$ had a lower feed intake and a better FCR than birds in the control group. Regarding the serological data, immunomodulators (Oregano oil plus $\beta$-glucan and Vitamin E plus selenium) used in present study were revealed a slight positive effect on antibody production against AI and ND vaccines. However, Propionibacterium acnes plus LPS of E. coli did not significantly change the serum IgG levels of broilers.

\section{Conflict of interest}

None of the authors have any conflict of interest to declare.

\section{References}

[1] Eterradossi, N. and Saif, Y.M. (2013): Infectious bursal disease. In:Swayne DE (Eds). Diseases of Poultry. 13ed. Oxford, UK: Wiley-Blackwell, p:219-246.

[2] Gallili, G.E. and Ben-Nathan, D. (1998): Newcastle disease vaccines. Biotechnol Adv, 16(2):343-366.

[3] Swayne, D.E. and King, D.J. (2003): Avian influenza and Newcastle disease. J Am Vet Med Assoc, 222(11): 15341540 .

[4] Yamuna, K. and Thangavel, A. (2011): Effect of Selenium and Vitamin E supplementation on Immune Status in Broiler Chickens. Tamilnadu J Vet Animal Sci, 7(6): 303-306.

[5] Dhama, K.; Chakraborty, S.; Wani, M.Y.; Verma, A.K.; Deb, R.; Tiwari, R. and Kapoor, S. (2013): Novel and emerging therapies safeguarding health of humans and their companion animals: a review. Pak J Biol Sci, 16(3): 101-111.

[6] Yu, J.; Shi, F.S. and Hu, S. (2015): Improved immune responses to a bivalent vaccine of Newcastle disease and avian influenza in chickens by ginseng stem-leaf saponins. Vet Immunol Immunopathol, 167(3):147155.

[7] Hou, R.; Chen, J.; Yue, C.; Li, X.; Liu, J.; Gao, Z.; Liu, C.; Lu, Y., Wang, D.; Li, H. and Hu, Y. (2016): Modification of lily polysaccharide by selenylation and the immune-enhancing activity. CarbohydrPolym, 142:73-81.

[8] Chan, G.C.; Chan, W.K. and Sze, D.M. (2009): The effects of B-glucan on human immune and cancer cells. J Hematol Oncol, 2(1):5-7. 
[9] Weickert, M.O. and Pfeiffer, A.F. (2008): Metabolic effects of dietary fiber consumption and prevention of diabetes. J Nutr,138(3):439-442

[10] Firenzouli, F., Gori, L. and Lombardo, G. (2008): The medicinal mushroom Agaricusblazei Murill: Review of literature and pharmaco-toxicological problems. Evid Based complement Alternat Med, 5(1):3-15.

[11] Harsini, S.G.; Habibiyan, M., Moeini, M.M. and Abdolmohammadi, A.R. (2012): Effects of dietary selenium, vitamin $\mathrm{E}$, and their combination on growth, serum metabolites, and antioxidant defense system in skeletal muscle of broilers under heat stress. Biol Trace Elem Res, 148(3):322-330.

[12] Vakili, R. and Daliri, R. (2010): The effect of different levels of vitamin $\mathrm{E}$ on humoral immunity, and performance in broiler chicks. J Vet Res, 65(3): 239244.

[13] Surai, P.F. (2002): Selenium in poultry nutrition: Antioxidant properties, deficiency and toxicity. World's Poult Sci J, 58(3):333-364.

[14] Colango, G.L.; Jensen, L.S. and Long, P.L. (1984): Effects of selenium and vitamin $\mathrm{E}$ on the development of immunity to coccidiosis in chickens. Poult Sci, 63(6):1136-1143.

[15] Marsh, J.A.; Dietert, R.R. and Coms, G.F. (1981): Influence of dietary selenium and vitamin $\mathrm{E}$ on the humoral immune response of chicks. Exp Biol Med, 166(2): 228-236.

[16] Marsh, J.A.; Combs, G.F.; Whitacre, M.E. and Dietert, R.R. (1986): Effect of selenium and vitamin $\mathrm{E}$ dietary deficiencies on chick lymphoid organ development. Exp Biol Med, 182(4):425-436.

[17] Perry, A.L. and Lambert, P.A. (2006): Propionibacterium acnes. Letters Appl Microbiol, 42:185-188.

[18] Tizard, I.R. (2009): Introducción a la InmunologíaVeterinaria. $8^{a}$ ed. Elsevier Saunders, Barcelona, Spain.
[19] Silhavy, T.J.; Daniel, K., and Suzanne, W. (2010): The bacterial cell envelope. Cold Spring Harbor perspectives in biology 2, no. 5 (2010): a000414.

[20] Al-Bandak, G. and Oreopoulou, V. (2007): Antioxidant properties and composition of Majorana syriaca extracts. Euro J Lipid Sci and Tech, 109(3): 247-255.

[21] Rhee, K. S., Anderson, L. M. and Sams, A. R. (1996): Lipid peroxidation potential of beef, chicken and pork. J Food Sci, 61(1):8-12.

[22] Walter, B. M. and Bilkei, G. (2004): Immunostimulatory effect of dietary oregano etheric oils on lymphocytes from growth-retarded, low-weight growing-finishing pigs and productivity. Tijdschr Diergeneeskd, 129(6):178-181.

[23] Volman, J.J.; Ramakers, J.D. and Plat, J. (2008): Dietary modulation of immune function by $\beta$-glucans. Physiol Behaviour, 94(2): 276-284.

[24] Kim, J.; Lee, S.M.; Bae, I.Y.; Park, H.G.; Gyu Lee, H. and Lee, S. (2011): (1-3) (1-6) $\beta$-Glucane-nriched materials from Lentinusedodes mushroom as a high-fiber and low-calorie flour substitute for baked foods. J Sci Food Agr, 91(10): 1915-1919.

[25] Li, Y. L.; Fu, A. K.; Chen, H. L.; Li, W. F. and Fu, L. Q. (2016): Potentiating effect of pidotimod on immune responses of chickens to live attenuated Newcastle disease vaccines. Ital $\mathbf{J}$ Animal Sci, 15(3): 536-544.

[26] Iren, B. (2000): Why do not grow sick individuums. GroBtierpraxis, 15:36-40.

[27] Williams, P. and Losa, R. (2001): The use of essential oils and their compounds in poultry nutrition. World Poult, 17(4):14-15.

[28] Christaki, E.V.; Bonos, E.M. and FlorouPaneri, P.C. (2011): Use of anise seed and/or $\alpha$-tocopheryl acetate in laying Japanese quail diets. S Afr J Anim Sci, 41(2):126-133.

[29] Hashemipour, H.; Kermanshahi, H.; Golian, A. and Veldkamp, T. (2013): 
Effect of thymol and carvacrol feed supplementation on performance, antioxidant enzyme activities, fatty acid composition, digestive enzyme activities, and immune response in broiler chickens. Poult Sci, 92(8): 2059-2069.

[30] Močár, K.; Stofan, D.; Angelovičová, M. and Liptaiová, D. (2010): The influence of feed mixtures with Origanum aetheroleum on broiler's production in the application of the principles of welfare. Anim Sci Biotechnol, 43(1):7983.

[31] Rathgeber, B. M.; Budgell, K. L.; MacIsaac, J. L.; Mirza, M. A. and Doncaster, K. L. (2008): Growth performance and spleen and bursa weight of broilers fed yeast beta-glucan. Can J Anim Sci, 88(3):469-473.

[32] Zhang, B.; Guo, Y. and Wang, Z. (2008): The modulating effect of $\beta$ $1,3 / 1,6$-glucan supplementation in the diet on performance and immunological responses of broiler chickens. Asianaustralas J Anim Sci, 21(2):237-244.

[33] Gaines, A. M.; Carroll, J. A.; Yi, G. F.; Allee, G. L. and Zannelli, M. E. (2003): Effect of menhaden fish oil supplementation and lipopolysaccharide exposure on nursery pigs II. Effects on the immune axis when fed simple or complex diets containing no spray-dried plasma. Domest Anim Endocrinol, 24(4):353-365.

[34] Yang, X.; Guo, Y.; He, X., Yuan, J.; Yang, Y. and Wang, Z. (2008): Growth

[35] Performance and immune responses in chickens after challenge with lipopolysaccharide and modulation by dietary different oils. Anim, 2(2):216-23.

[36] Korver, D.R. and Klasing, K.C. (1997): Dietary fish oil alters specific and inflammatory immune responses in chicks. J Nutr, 127(10):2039-2046.

[37] Rahimi, S.; Teymouri Zadeh, Z.; Torshizi, K.; Omidbaigi, R. and Rokni, H. (2011): Effect of the three herbal extracts on growth performance, immune system, blood factors and intestinal selected bacterial population in broiler chickens. J Agric Sci Technol, 13:527539.

[38] Acamovic, T. and Brooker, J. D. (2005): Biochemistry of plant secondary metabolites and their effects in animals. Proc Nutr Soc, 64(3):403-412.

[39] Gabor, E.F.; Sara, A. and Barbu, A. (2010): The effects of some phyto additives on growth, health and meat quality on different species of fish. Anim Sci Biotechnol, 43(1):61-65.

[40] Feizi, A. and Nazeri, M. (2011): Thyme essential oils (Thymus vulgaris) alleviate vaccination reactions in broiler chickens. Ann Biol Res, 2:464-468.

[41] Vázquez, R.S.; Meléndez, L.A.D.; Estrada, E. S.; Rodríguez Muela, C.; Villalobos, G. V.; Zamora, G.M. and Hume, M.E. (2015). Performance of broiler chickens supplemented with Mexican oregano oil (LippiaberlandieriSchauer). Rev Bras de Zoot, 44(8): 283-289.

[42] Mosleh, N.; Shomali, T. and AghapourKazemi, H. (2013): Effect of Zataria multiflora essential oil on immune responses and faecal virus shedding period in broilers immunized with live Newcastle disease vaccines. Iran J Vet Res,14(3): 220-225.

[43] Swain, B. K.; Johri, T. S. and Majumdar, S. (2000): Effect of supplementation of vitamin $\mathrm{E}$, selenium and their different combinations on the performance and immune response of broilers. Br Poult Sci, 41(3): 287-292.

[44] Özkan, S.; Malayoğlu, H.B.; Yalcin, S.; Karadaş, F.; Koçtürk, S.; Cabuk, M.; Oktay, G.; Özdemir, S.; Özdemir, E. and Ergül, M. (2007): Dietary vitamin E ( $\alpha$ tocopherol acetate) and selenium supplementation from different sources: Performance, ascites-related variables and antioxidant status in broilers reared at low and optimum temperatures. $\mathrm{Br}$ Poult Sci, 48(5):580-593.

[45] Moriguchi, S.; Miwa, H.; Okamura, M.; Maekawa, K.; Kishino, Y. and Maeda, K. (1993): Vitamin E is an important factor in $\mathrm{T}$ cell differentiation in thymus 
of F344 rats. J Nutr Sci Vitaminol, 39(5):451-463.

[46] Tampieri, M.P.; Galuppi, R.; Macchioni, F.; Carelle, M.S.; Falcioni, L.; Cioni, P.L. and Morelli, I. (2005): The inhibition of Candida albicans by selected essential oils and their major components. Mycopathol, 159(3): 339345 .

[47] Ferrer, L.M.; Fernández, A.; Loste, A.; Ortín, A.; Lacasta, D.; Ramos, J.J. and
Conde, T. (2013): Effect of oral administration of Propionibacterium acnes on growth performance, DTH response and anti-OVA titers in goat kids. Pesq Vet Brasil, 33(1): 5-10.

[48] Flaminio, M.J.B.; Rush, B.R., and Shuman, W. (1998): Imunologic function in horses after non-specific immunostimulant administration. Vet immunol immunopathol, 63(4): 303-315.

\section{الملخص العربى}

تقييم مقارن لبعض المحفزات المناعية على رد الفعل المناعى في بدارى التسمين ضد تحصينات انفلونزا الطيور والنيوكاسل

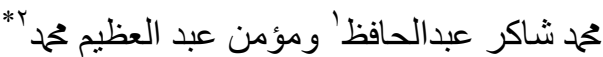

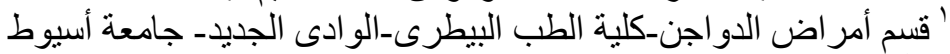

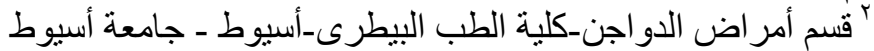

إن استخدام المحفزات المناعية جذب مزيد من الإهتمام لتقوية الجهاز المناعى و تحسين الاداء فى انتاج الدواجن. تناولت هذه الإهي

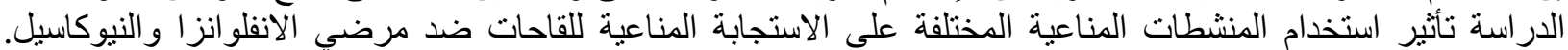

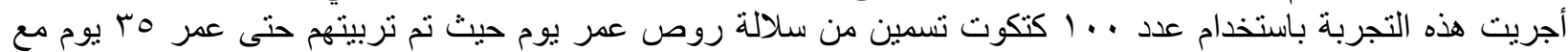

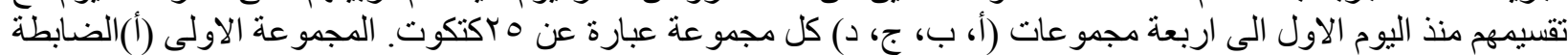

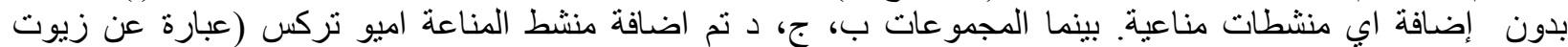

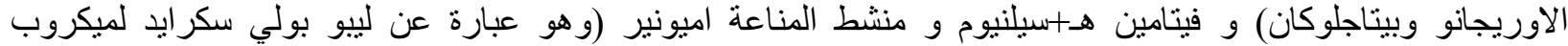

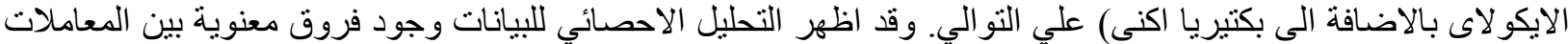

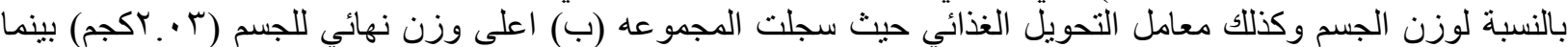

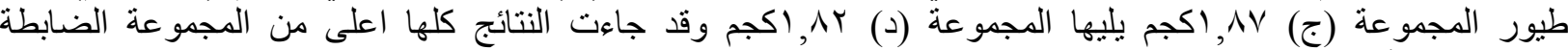

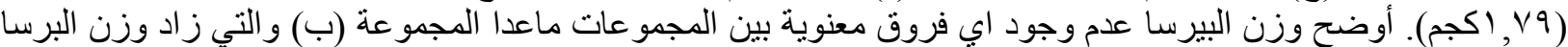

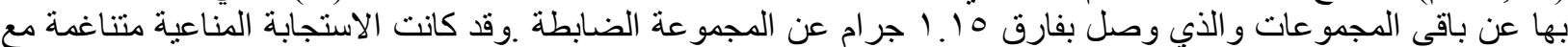

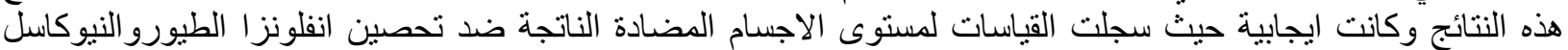

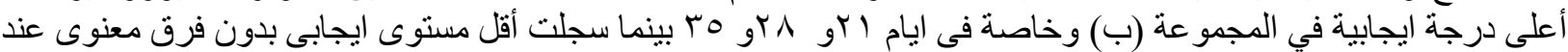

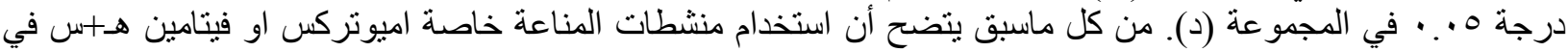

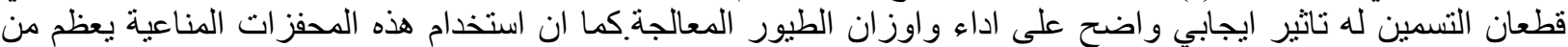

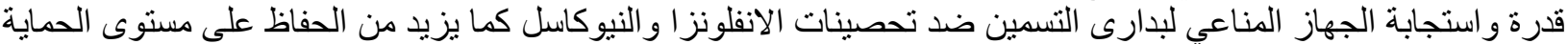

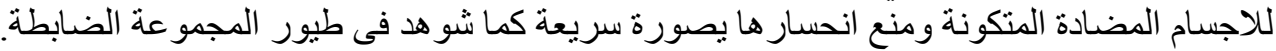

